Bangladesh Journal of Anatomy January 2013, Vol. 11 No. 1 pp 34-43

\title{
Medical Undergraduates' Residual Knowledge of Structural, Functional and Clinical Aspects of Cell and Histology at Recall and Understanding Levels
}

\author{
Nahid Farhana Amin ${ }^{1}$, Manowara Akter ${ }^{2}$, Mohammed Humaun Kabir ${ }^{3}$, \\ Khondker Manzare Shamim ${ }^{4}$
}

\begin{abstract}
Context: The importance of the knowledge of Cell and Histology in grasping the paraclinical and clinical sciences by medical undergraduates is understandable. The rapidly changing scenario of the concepts of teaching-learning and assessment demands assessing the status of undergraduates' residual knowledge from the viewpoint of teachers, curriculum planners and educational researchers.
\end{abstract}

Materials and methods: Answering text-based (60\%) and illustration-based (40\%) single-sentence True/ False questions was attempted by 373 undergraduates who had completed the Cell and Histology portion of their course 3 to 6 months earlier in two government and two private medical colleges of Bangladesh. There were structurally-oriented (46.67\%), functionally-oriented (43.33\%) and clinically-oriented (10\%) questions addressing mainly recall (58\%) and understanding $(40.67 \%)$ levels of cognitive domain. Comparisons were made among the numbers of correct answers to different types of question using ANOVA Post Hoc and t test, as applicable.

Results: The mean frequency of correct response was $54.25 \%$. Significantly more $(p=0.00)$ correct responses were recorded for the clinically-oriented (62.47\%) and functionally-oriented (54.46\%) questions than for the structurally-oriented (52.62\%) questions. There were significantly $(p=0.00)$ fewer correct responses for the understanding-level questions (51.13\%) than for the recall-level questions (56.65\%).

Conclusion: These results suggest that the residual knowledge of Cell and Histology in the undergraduates, though not very rich, may be governed both by a sense of relevance and by memorisation. Further study with a larger sample can add to these results to dictate curriculum modification and implementation, regarding teaching and assessment, in making learning more relevant and less memorisation-dependent.

Key words: Medical undergraduates, residual knowledge, Cell and Histology, structural, functional, clinical, recall, understanding, levels of cognitive domain, learning.

\section{Introduction}

In today's world, the way we think about learning has been changing in the light of newer evidences revealed every day. Understandably, the changes influence our teaching and assessment methods as well as the teaching/learning (instructional) materials or tools we use.

1. Assistant Professor, Department of Anatomy, Bangabandhu Sheikh Mujib Medical University (BSMMU), Dhaka

2. Associate Professor, Department of Anatomy, Tairunnesa Memorial Medical College, Gazipur

3. Support Team Member, HEQEP CP-036, Department of Anatomy, BSMMU, Dhaka

4. Professor \& Chairman, Department of Anatomy, BSMMU, Dhaka

Correspondence: Dr. Nahid Farhana Amin
Planning for the learning of Anatomy is experiencing its share in that change. Anatomy is one of the foundational sciences in the undergraduate medical curriculum, and Cell and Histology are integral parts of Anatomy. Clinical anatomy is a bridge between the students and practitioners on one side and the patients on the other ${ }^{1}$. Some authors have specifically highlighted functional and clinical correlations of Cell and Histology 2,3,4. For being a good physician, one must understand both normal and abnormal structures and functions and dysfunctions of cells, tissues and organs. Then only, one can become a critical thinker which helps to recognise and interpret diseases, thus emphasizing proper application of cell and histology in medical science. 
However, though systematic studies that could provide useful evidence on the teaching-learning or assessment in Cell and Histology have been few in our country ${ }^{5,6}$, it is felt that the undergraduate courses of Bangladesh are not being able to meet the demands of time in every aspect of these subdivisions of Anatomy. Teachers often complain that students seldom develop proper understanding and resort instead to rote memory and non-visual theoretical information-gathering. As "Histology sets the stage for subsequent studies of abnormal structure and function"7, the situation raises serious concerns. But even in the US, there conflicting views among the stakeholders. In a study on US physicians ${ }^{8}, 88 \%$ felt that Histology was important for the medical curriculum, and $66 \%$ said that they used their Histology knowledge often (weekly or daily). On the other hand, a population of US medical students ranked their study of Gross Anatomy almost 3 times higher than that of Histology in preparing for their clinical clerkships and electives (Miller et al. 2002 cited by Burns ${ }^{9}$ ).

In recent years, some positive developments have been made in the organisation of teaching-learning and assessment in Cell and Histology in Bangladesh. A new curriculum has been effective since the beginning of $2014^{10}$. Earlier, some guidelines had been formulated for assessment that were published as an adjunct to the previous curriculum ${ }^{11}$. Such a module following the new curriculum is yet to be published.

As cell and Histology went on flourishing with time, the demand for their importance has been increasing from the scientific community and the society as a whole in relation to the medical profession. This calls for proper and useful curriculum design for ensuring a desirable outcome. An essential component of curriculum design is the assessment of needs that may take different forms, and may approach from different perspectives.

But the nature and diffusion of the philosophical understanding that should govern these changes is not easy to measure. Therefore, analyses of the performance of the medical undergraduates on their residual knowledge of Cell and Histology should indirectly be able to provide an understanding of the modern-day teaching-learning trends in the subjects. This understanding, in turn, can guide the curriculum planners in bringing about necessary modifications in the curriculum. Keeping the above rationale in mind, the following objectives were set for the study:

1. To assess the performance of undergraduate medical students in answering functionally- and clinically-oriented questions as compared to their performance in answering structurallyoriented questions on Cell and Histology.

2. To assess the performance of undergraduate medical students in answering understandinglevel questions as compared to their performance in answering recall-level questions on Cell and Histology.

\section{Materials and Methods}

The study was analytical in nature carried out in the Department of Anatomy, Bangabandhu Sheikh Mujib Medical University (BSMMU), Dhaka.

Operational definitions (see examples in Table-1)

Residual knowledge (of Cell or Histology): The amount and type of knowledge (of Cell or Histology) that were retained three to six months after the summative exams had been taken, as an indicator of the knowledge residue of what had been learnt in the $1^{\text {st }}$ two years of medical undergraduate course.

Text-based question: A question based on a textual material (material written in words) of the book.

Illustration-based question: Aquestion based on any form of picture presented as a 'figure' in the textbook (photograph, photomicrograph, electron micrograph, realistic diagram, semi-realistic diagram, schematic diagram, flow chart or diagnostic image).

Structurally-oriented question: Aquestion based on textual description or an illustration of the structural features of tissue and cellular components at the light microscopic, electron microscopic or molecular level.

Functionally-oriented question: A question based on texual description or an illustration depicting functional aspect(s) of tissue or cellular components at the light microscopic, electron microscopic or molecular level.

Clinically-oriented question: A question constructed on the basis of information, explanation or concept related to the clinical correlation of cellular or histological features. 
Recall-level question: A question addressing the student's remembering of previously learned material, specific facts to complete theories.

Understanding-level question:Aquestion addressing the student's ability to grasp the meaning of a material.

Application-level question: A question addressing the student's ability to use learned material in new and concrete situations.

\section{Table-I}

Examples of different types of question included in the question paper

\begin{tabular}{|c|c|c|c|c|c|c|c|}
\hline Question T & $\mathbf{T}$ & I & $\mathbf{S}$ & $\mathbf{F}$ & C & $\mathbf{R}$ & $\mathbf{U}$ \\
\hline $\begin{array}{l}\text { Cardiac muscle cells } \\
\text { characteristically possess } \\
\text { 'triads' composed of one } \\
\text { T tubule and two sarcoplasmic } \\
\text { reticulum cisternae. }\end{array}$ & $\checkmark$ & & $\checkmark$ & - & - & $\checkmark$ & \\
\hline $\begin{array}{l}\text { The cell membrane acts as a } \\
\text { selective barrier so that the } \\
\text { intracellular and extracellular } \\
\text { environments remain the same. }\end{array}$ & & $\checkmark$ & - & - & $\checkmark$ & - & \\
\hline $\begin{array}{l}\text { A 3-year-old boy was bitten } \\
\text { by a snake } 6 \text { months back but } \\
\text { recovered easily. A second bite } \\
6 \text { months later caused very } \\
\text { severe complications. This is } \\
\text { due to anaphylactic shock from } \\
\text { must cell action. }\end{array}$ & $\checkmark$ & - & - & - & $\checkmark$ & - & \\
\hline
\end{tabular}

Figure 4 shows that compare $\quad-\checkmark-\begin{array}{lllll} & - & - & -\end{array}$ to structure 'A', structure 'D'

shows more evidence of protein secretory organelles.

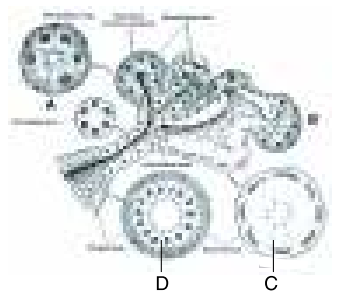

Figure 28 is a three-dimensional $-\checkmark \checkmark-\quad-\checkmark-$ view of a surface in a scanning electron micrograph.

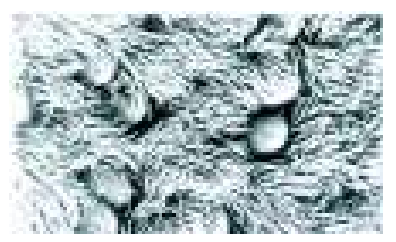

T: Text-based question, I: Illustration-based question, S: Structurally-oriented question, F: Functionally-oriented question, C: Clinically-oriented question, R: Recall-level question, U: Understanding-level question, A: Application-level question

\section{Basis of construction of the question paper}

The Histology textbooks for medical undergraduates contain both text and illustrations. Therefore, in preparing the question paper for the present study, use of both text and illustration was kept in mind. There were 150 questions, of which 90 were textbased and 60 were illustration-based. In two internationally acclaimed Histology textbooks ${ }^{12,13}$ commonly recommended in Bangladesh for the medical undergraduates, the average amounts of textual materials and illustrations are more or less similar, with illustrations having a higher value ${ }^{5}$. But the module of the first professional MBBS examination ${ }^{11}$ has $66 \%$ marks allotted to text-based questions and $34 \%$ to illustration-based questions. Keeping this in mind, it was decided to construct a question paper containing $60 \%$ text-based questions and $40 \%$ illustration-based questions for the present study. For constructing the questions based on illustrations, priorities were given to the importance and/or purposes of the illustrations. In this way 30 illustrations were selected for constructing 60 illustration-based questions. Selected illustrations were scanned and necessary modifications were made in the computer regarding clarity, size, simplicity of labeling etc. All questions were based on the text and illustrations of one of the commonly recommended textbook ${ }^{12}$.

For constructing questions from a particular chapter of the textbook, the proportion of pages allotted to that chapter was calculated. This proportion was used as a measure of weight of the chapter in determining the number of questions to be constructed from that chapter in a broader sense Table-II. Out of the 23 chapters of the book, 21 were used for preparing the question paper (excluding two chapters related to 'blood' as 'blood' is included in Physiology in the undergraduate curriculum). Three to eleven questions were constructed from each chapter.

Table-II

Numbers of questions constructed from different groups of chapters of the textbook

\begin{tabular}{lcc}
\hline Chapter group & $\begin{array}{c}\text { No. of } \\
\text { chapters }\end{array}$ & $\begin{array}{c}\text { No. of } \\
\text { questions }\end{array}$ \\
\hline Chapters on cell & 2 & 18 \\
Histology and its methods of study & 1 & 7 \\
Chapters on the basic tissues & 7 & 40 \\
Chapters on systemic histology & 11 & 85 \\
Total no. & 21 & 150 \\
\hline
\end{tabular}


Of the 150 questions, 70 (46.67\%) were structurallyoriented, $65(43.33 \%)$ functionally-oriented and $15(10 \%)$ clinically-oriented. They also addressed different levels of cognitive domains. Thus, 87 (58\%) questions were of recall-level and 61 (40.67\%) of understandinglevel. There were also 2 application-level questions; but for the analytical part of the study, these two were not considered. So, 148 questions were analysed for assessing the recall and understanding levels of cognitive domain. Table -III shows the numbers of different types of questions.

Table-III

Numbers of different types of question included in the question paper addressing different levels of cognitive domain

\begin{tabular}{lrrrr}
\hline Type of question & \multicolumn{4}{c}{ Type of question by orientation } \\
\cline { 2 - 5 } $\begin{array}{l}\text { by level of cog- } \\
\text { nitive domain }\end{array}$ & Structural Functional & Clinical & Total \\
\hline Recall & 50 & 30 & 7 & 87 \\
Understanding & 20 & 35 & 6 & 61 \\
Application & 0 & 0 & 2 & 2 \\
Total & 70 & 65 & 15 & 150 \\
\hline
\end{tabular}

As our aim was to judge the residual knowledge of the students, we put emphasis on the important subheadings to cover the important topics of each chapter in preparing questions. Only single-sentence True / False type of questions were constructed for the test.

\section{Participants and conduction of the study}

The undergraduate medical students who had completed the Cell and Histology portion of their course (i.e., who had passed the First Professional MBBS Exams and were in the 'New third year') were considered eligible as the study participants. Two government and two private medical colleges of Bangladesh were chosen through convenience sampling. With formal permission from the authorities of each medical college, a lecture class was chosen which is usually attended by a large number of students. The students present in that class were taken as the participants. Thus, a total of 373 students participated.

A printed question paper was handed over to them and 90 minutes were allotted for answering the 150 questions on the question paper itself. The time period passed between the time of the summative exam in which the students were assessed for Cell and Histology and the time of the present study varied between three and six months in different colleges.

Methods of analyses of the undergraduates' performances

The numbers of correct responses to different types of question were counted. As all the data were more or less normally distributed, the ANOVA Post Hoc test was used to judge the performance in responding correctly to the functionally-oriented and clinically-oriented questions separately compared to that in responding correctly to the structurallyoriented questions. Paired t test was used to judge the undergraduates' performances in responding correctly to the understanding-level questions compared with the recall-level questions.

\section{Results}

The quantitative data of the three types of responses ('correct', 'incorrect' and 'unattempted') in answering structurally-, functionally- and clinically-oriented questions as well as questions addressing different levels of cognitive domain were compared visually by using bar diagrams and histograms.

The overall mean frequency of correct responses was $54.25 \%$ as shown in Figure 1.

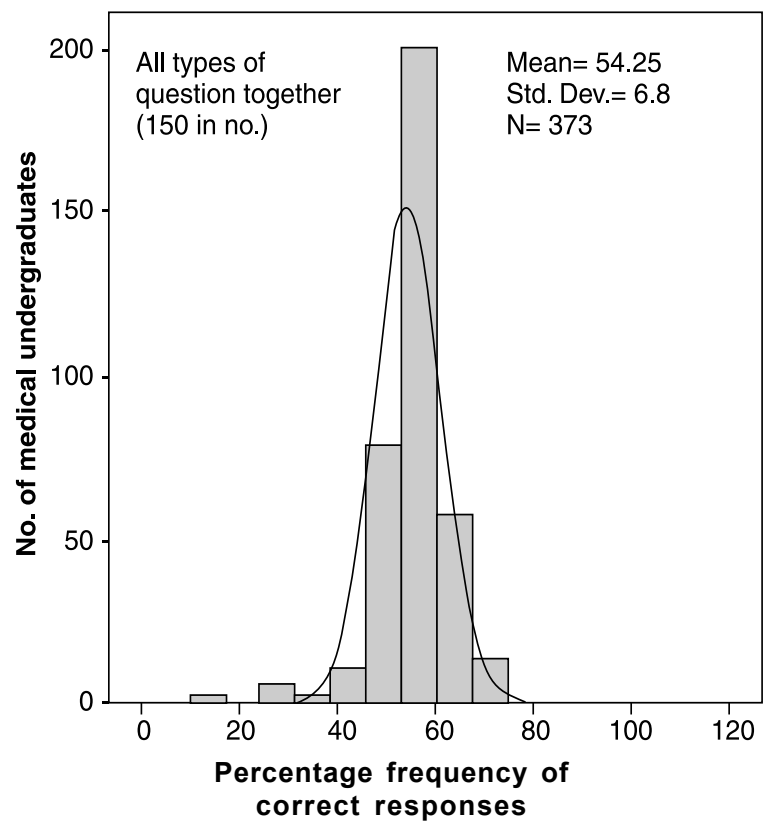

Fig.1: Frequency distribution of correct responses to all types of questions. 
Performances in answering structurally-, functionally-, and clinically-oriented questions

The performance of the medical undergraduates in answering the functionally-oriented questions was significantly $(p=0.000)$ better than that in answering the structurally-oriented questions. Similar was the performance in answering the clinially-oriented questions. The means of correct, incorrect and unattempted responses can be compared visually in Figure 2. Although the mean frequency of correct responses in answering the clinically-oriented questions was $62.47 \%$, it was less than $60 \%$ in answering both the structurallyoriented and functionally- oriented questions (Figure 2).

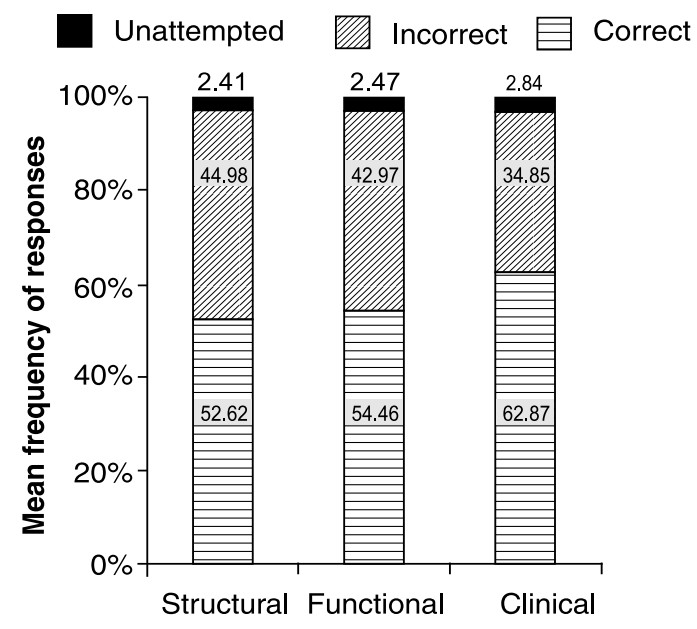

Type of question by orientation

Fig.-2: Comparisons of the mean frequencies of correct, incorrect and unattempted responses to the structurally-, functionally- and clinically-oriented questions.

The frequency distributions of correct responses to these three types of question show a slight rightward shift (i.e., higher values) for the functionally-oriented questions compared to the structurally-oriented questions. Further rightward shift with a broader distribution is seen for the clinically-oriented questions (Figure 3 ).
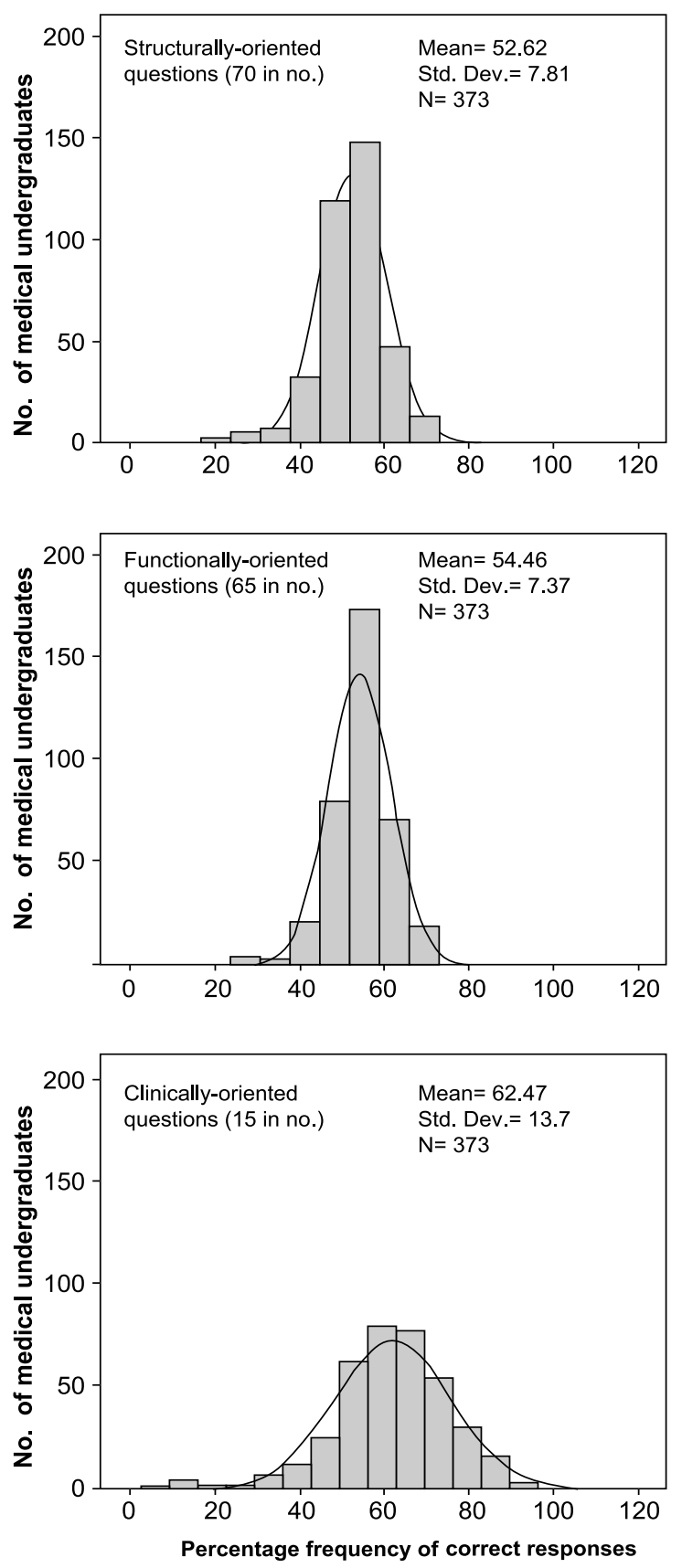

Fig.-3: Comparisons among the frequency distributions of correct responses to the structurally, functionally-and clinically-oriented questions.

Medical undergraduates' ability to answer recalland understanding-level questions

The performance of the undergraduates in answering the understanding-level questions was significantly $(p=0.000)$ poorer than that answering the recall- 
level questions. The means of the correct, incorrect and unattempted responses can be compared visually in Figure 4.

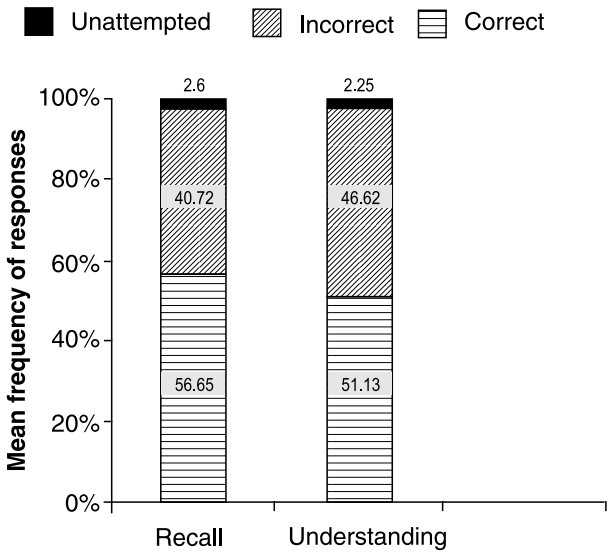

Type of question by level of cognitive domain

Fig.-4: Comparison between the mean frequencies of correct, incorrect and unattempted responses to the recall- and understanding-level questions.
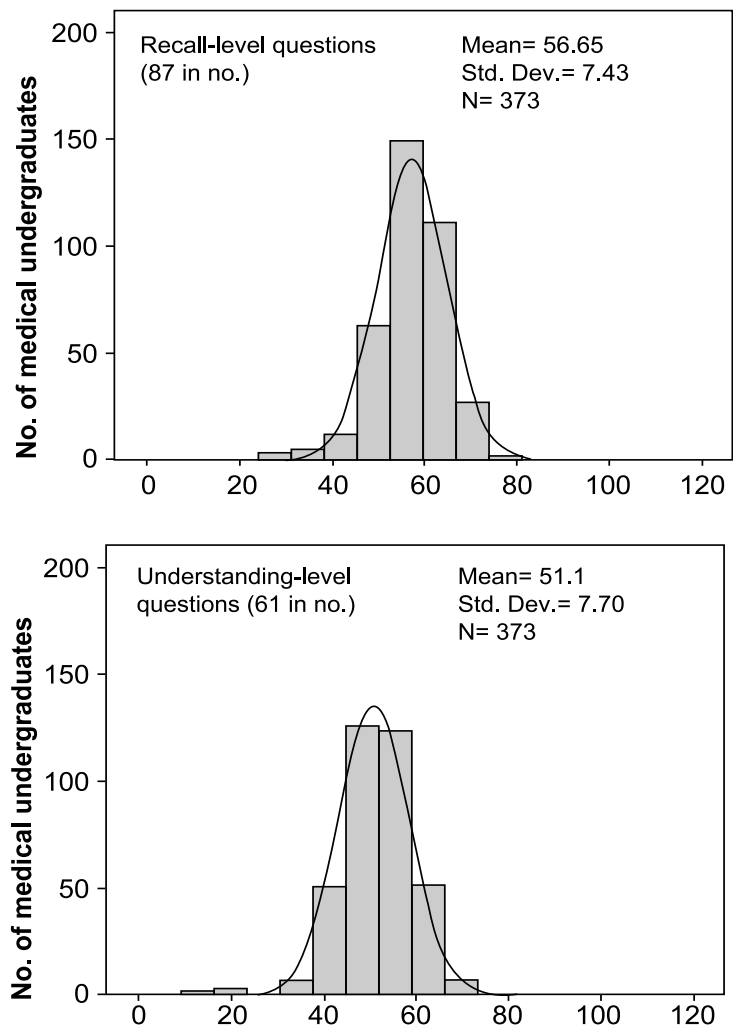

Percentage frequency of correct responses

Fig.-5: Comparison between of the frequency distributions of correct responses to the understanding-level and recall- level questions .
The figure also shows that the mean frequencies of correct responses were less than $60 \%$ in answering these two types of question.

The frequency distributions of correct responses to these two types of question show a leftward shift (i.e., lower values) for the understanding-level questions compared to the recall-level questions (Figure 5).

\section{Discussion}

The present study was done with a hope to contribute to the advancement of teaching-learning and assessment in Cell and Histology in the undergraduate medical courses of Bangladesh. Debates and experimentations are going on around the world with a wide range of views about the teaching-learning and assessment in these subdivisions of Anatomy. Students' performances are likely to provide insight into the problems specific to the country that would be useful in curricular modification and implementation.

\section{Importance of structure-function correlation}

The overall better student performance regarding functionally-oriented questions than structurallyoriented questions in the present study is encouraging. The importance of structure-function correlation in the field of Histology can be realised by understanding the following statement from Wheater et $\mathrm{al}^{14}$. "Histology has bored generations of students ..........almost certainly because it has been regarded as the study of structure in isolation from function". Junqueira and Carneiro ${ }^{12}$ believe that if the students examine the structure of an organ or tissue, they can deduce much about its function. Conversely, if they know its function, they can forecast more easily much of its microscopic structures. Thus, "Histology stands at the crossroads between gross anatomy and physiology and acts as an integrat ive element between them"15. Leeson et al. ${ }^{16}$ also assert that "the correlation between structure and function is essential. Some authors $^{12,16}$ emphasize that the integration of structural and functional aspects of Histology (i.e. Cell and Histology) is essential for better understanding of this subject. This needs to be reflected in our curriculum, including assessment. Universities in various parts of the world have 
addressed this important realisation while designing their courses. In the University of lowa College of Medicine, the departmentally based courses, General Histology for Medical students, and Medical Physiology, have been folded into a single structure-function course entitled 'Human organ systems' 17 .

\section{The question of relevance}

We know that adult learners want to know the relevance of what they are learning to what they want to achieve ${ }^{18}$. A medical undergraduate would like to be able to understand structural features of cells and tissues in the context of their physiological implications. In addition, beginning medical students deserve to be shown the relevance of histology to medicine, as Burns ${ }^{9}$ thinks. New learning builds on previous learning experiences. It has been suggested that "relevant, meaningful activities that both engage students emotionally and connect with what they already know" may build neural connections and long-term memory storage ${ }^{19}$. Teachers therefore should make students recognise patterns and put new information in context with the old ${ }^{19}$. If the curriculum planners can specify the amount of clinical conditions related to histology that must be learnt, and also incorporate this into the assessment, then students may get interested in learning about them.

The importance of clinical correlation

Significantly better performance was demonstrated by the undergraduates regarding the clinicallyoriented questions than structurally-oriented questions. There are no disease processes which do not involve cells/tissues ${ }^{9}$. Fawcett ${ }^{3}$ believes that a firm foundation in Histology is essential for recognising and interpreting their changes in disease. It also helps in understanding the disease process. A tissue diagnosis is also essential before starting treatment involving major surgery, radiation, or drugs, Fawcett adds ${ }^{3}$. More importantly, emphasis needs to be placed on normal processes that may be confused with pathologic conditions (Mills and Stacey ${ }^{20}$ ). Gupta et al. ${ }^{21}$ believe that improvement of the subject of Histology is sufficient to upgrade their concept in pathology. In a study of the 'Preface's of histology books regarding their presentation patterns, 10 out of 15 were found to highlight clinical correlation of histology 22 .
It is also asserted that understanding how cells work in healthy and diseased states, cell biologists have been and will be able to develop new vaccines and more effective medicines, fight infertility and develop a better understanding of how all living things live. It should be noted that "Clinical Anatomy' is a declared component of the course content of the MBBS (i.e., undergraduate) curriculum ${ }^{10}$ recently updated for different universities of Bangladesh. In recent years, there has been a trend towards making undergraduate teaching more clinically-oriented. It is difficult to assess the weight assigned to the clinical aspect of Cell and Histology in our undergraduate curriculum.

It must be realised that undergraduate medical students are would-be doctors. The Cell and Histology to be learned by them must be oriented towards the development of a doctor rather than an anatomist. Some anatomists of our country thought that Histology is a very difficult subject. However, it is essential to realise that as a criterion for inclusion in the course content curriculum planners must put more emphasis on the 'importance' of a topic in terms of the expected outcome of a course rather than its 'difficulty level'.

The question of physio-clinical integration of Cell and Histology

It should be remembered that the objective of learning Cell and Histology is not only to understand normal structures and functions but to integrate it with clinical conditions. Clinically-oriented Histology teaching is not a new concept in most of the medical schools abroad, which is also reflected in the Histology textbooks commonly used by the undergraduate medical students of Bangladesh. Now-a-days, integrated teaching of Histology, Physiology and Pathology is well practised in some renowned universities of the world. In the University of New South Wales, Australia, learning of histology has been successfully integrated with histopathology ${ }^{23}$. Some integration of Anatomy with Physiology and Biochemistry has been introduced in our new curriculum. This mentions only gross Anatomy, not Cell or Histology. Much may not be possible to achieve in our colleges within a short time, but it is a good move. 
Addressing higher levels of cognitive domain

In the present study, the performance of the undergraduates in answering understanding-level questions was significantly poorer than in answering recall-level questions.

The simplified version of taxonomic classification suggested by Bloom et al. envisages only a three level classification which can be practised easily. Accordingly, a question paper should include questions to assess at least the following levels of cognitive domain: Recall (knowledge), Understanding (comprehension) and Application (problem solving).

The undergraduate Anatomy curriculum of Bangladesh has allotted $60 \%$ questions for the recall-level, $30 \%$ for the understanding-level and $10 \%$ for the application-level of cognitive domain. However, in practice, the application-level questions are rarely found in the exam papers. Nahid ${ }^{5}$ found no application-level question on Cell or Histology in the question papers of four Bangladeshi universities from 2005-2007. Considering this rarity, the question paper of this study was prepared with $58 \%$ recalllevel questions and about $11 \%$ understanding-level questions. Application-level questions were just more than $1 \%$. For this low number, no statistical analysis was done for comparing the performances in answering the application-level questions with the other two levels. Moran and Rowley ${ }^{24}$ have realised that "anything is simple once you understand it". Again, more comprehensive knowledge should be more lasting.

It is understandable that most of the proportion of the application-level questions recommended in Bangladeshi curriculum is supposed to be covered from Regional Anatomy, developmental Anatomy and Neuroanatomy portions of the curriculum. In the same way, the Cell and Histology should be learned and assessed by using application-level questions, and then it increases the critical thinking level of the students. Critical thinking assures students that their knowledge and understanding is being directed towards something useful in their future carrier as doctors. Reygel et al. ${ }^{25}$ has mentioned some approaches for minimizing memorisation.
For improving the situation in Bangladesh, every effort should be made to focus the attention of teaching Cell and Histology towards the understanding level so that the students get more interest in studying the subjects. It is understandable that students can manage the learning of recalllevel information mostly by themselves. They need to be motivated by the teachers to realise the importance of addressing understanding, application and higher levels of cognitive domain. This approach should also be reflected in the assessment system making students eager to understand, apply and go up the levels of cognitive domain. Understandingand clinical-type statements found in Histology books may be used for creating understanding or application-level questions. This approach conforms to Tanner's ${ }^{26}$ suggestion that in studying scientific topics, more emphasis has to be put on understanding scientific concepts and developing inquiry abilities than on merely knowing scientific facts and information. Activities that investigate and analyse science questions also deserve more emphasis than activities that simply demonstrate and verify science content ${ }^{26}$. For achieving such goals, specific objectives should be formulated somewhat similar to the following ${ }^{27}$ (so that both teachers and students understand what they have to achieve):

- Describe / Identify / Recognize / Correlate between the microscopic structures and function of the different cells tissues and organs of the body.

- Correlate the defective structure of cells and tissue to relevant clinical applications.

- Integrate basic histological knowledge with clinical data interpret the structural changes in cells to understand the underlying cause of different disease solve problem related to structural dysfunction.

\section{Other points and limitations of the study}

It is interesting to find statistically more correct answers to functionally- and clinically -oriented questions than to structurally- oriented questions, especially when the participants did poorer with the understanding- level questions than with the recall- 
level questions. One cannot jump to conclusions with only one study of this sort, where 150 questions might have many aspects that have worked in determining whether correct answers would come up. We have remembered that each question was a combination of at least three distinct features: i) text-based or illustration-based, ii) structurallyoriented, functionally-oriented or clinically-oriented and iii) recall-level, understanding-level or application or level.

Moreover, it is hard to construct, for example, a purely 'functionally-oriented' or 'understanding-level' question. In answering a functionally- oriented question, a student might have unknowingly used his/her structural knowledge. Similarly, some amount of recalling must have contributed while answering as 'understanding'-level question. Crossing-over of the "three features" was another possibility. For example, a visual learner doing good on an illustration-based understanding-level question than on a text-based recall- level question. There is another possible confounder with the mean frequency of 'unattempted responses' being below $3 \%$ (Figures 2 and 4), especially when the overall mean frequency did not cross even $55 \%$, there is a possibility that a good number of students have 'taken chances' in cases where they did not have any idea about the possible answer. This might have been aggravated by the fact that the questions were single-sentence T/F type - asking for too little.

Nevertheless, the results of the present study may suggest that Bangladeshi medical undergraduates are possibly more interested in memorising than in understanding in dealing with Cell and Histology. The better performance in answering functionallyand clinically- oriented questions than in answering structurally-oriented questions is difficult to explain, especially when informal experiences suggest the contrary. However, the following possibilities cannot be overuled; a) that the functionally- oriented aspects have an inherent nature of not based much on rote memory: b) clinical aspects do create some subconscious interest in the students because of their relevance in their life.

\section{Conclusions}

These preliminary results showing better performance in answering functionally- and clinicallyoriented questions compared to structurally- oriented questions and poorer performance regarding understanding- level questions than recall- level questions may suggest that the residual knowledge of Cell and Histology in the undergraduates, though not very rich, may be governed both by a sense of relevance and by memorisation. Further study with a larger sample can add to these results to dictate curriculum modification and implementation, regarding teaching and assessment, in making learning more relevant and less memorisationdependent.

\section{Acknowledgement}

This study was a part of subproject CP036 of the Higher Education Quality Enhancement Project (HEQEP) of the University Grant Commission of Bangladesh.

\section{References}

1. Akter M. Analyses of undergraduate written questions and medical undergraduates' ability to answer illustration-based and clinicallyoriented questions in neuroanatomy compared to non-illustration-based and non-clinicallyoriented questions. Thesis (MPhil). Bangabandhu Sheikh Mujib Medical University. 2010.

2. Telser AG, Young JK, Baldwin KM. Elsevier's integrated histology. Philadelphia: Mosby Elsevier; 2007.

3. Fawcett DW, ed. Bloom and Fawcett: a textbook of histology. $12^{\text {th }}$ ed. New York: Chapman and Hall; 1994.

4. Sligtenhorst IV, Bick RJ. Inclusion of an integrated team based learning session in first year Histology is well received, but who fares well and who benefits? The Open Medical Education Journal 2011; 4:18-23.

5. Amin NF. Recent trends in the presentation of cell biology and histology in the histology books and their reflections in the written summative assessment at the medical 
undergraduate level in Bangladesh. Thesis (MPhil). Dhaka. Bangabandhu Sheikh Mujib Medical University. 2008.

6. Refauddin K. Changes in the use of illustrations in a histology textbook through editions and feedback from anatomists and medical undergraduates about using illustrations in cell biology and histology teaching-learning and assessment. Thesis (MPhil). Bangabandhu Sheikh Mujib Medical University. 2010.

7. Cormack DH, ed. Ham's Histology. $9^{\text {th }}$ ed. Philadelphia: J.B. Lippincott Company; 1987.

8. Pratt RL. Are we throwing histology out with the microscopy? A look at histology from the physician's perspective. Anatomical Sciences Education 2009; 2:205-209.

9. Burns ER. Clinical histology. Clinical Anatomy 2006; 19:156-163.

10. Dhaka Medical College. Curriculum for undergraduate medical education in Bangladesh: updated 2012- Approved by Bangladesh Medical and Dental Council (BM\& DC). 2012.

11. Faculty of Undergraduate Medicine, University of Dhaka. Module on $1^{\text {st }}$ professional MBBS examination system to be held on January 2008 based on new curriculum. 2008.

12. Junqueira LJ, Carneiro J. Basic histology- text and atlas. $11^{\text {th }}$ ed. New York: McGraw-Hill; 2006.

13. Ross MH, Pawlina W. Histology: a text and atlas with correlated cell and molecular biology. $5^{\text {th }}$ ed. Baltimore: Lippincott Williams and Wilkins; 2006.

14. Wheater PR, Burkitt HG, Daniels VG. Wheater's functional histology: a text and colour atlas. $1^{\text {st }}$ ed. Edinburgh: Churchill Livingstone; 1979.

15. Gartner LP, Hiatt JL. Color textbook of histology. 2nd ed. Baltimore: Saunders; 2001.

16. Leeson TS, Leeson CR, Paparo AA. Text/atlas of histology. Philadelphia: W.B. Saunders Company; 1988.

17. Heidger JR, PM, Dee F, Consoer D, Leaven T, Duncan J, Kreiter C. Integrated approach to teaching and testing in histology with real and virtual imaging. The Anatomical Record (New Anatomist). 2002; 269:107-112.

18. Queensland Occupational Therapy Fieldwork Collaborative. Adult learning theory and principles. 2007. (Available from: webservices@uq.edu.au [accessed on January 22, 2014 ])

19. Bernard S. Personal relevance is as vital to the learning brain as it is to the person learning. The George Lucas Educational Foundation; 2010. (Available from: www.edutopia.org/ neuroscience-brain-learning-relevanceimproves-engagement [accessed on January 22, 2014])

20. Mills MD, Stacey E. Histology for pathologists. $3^{\text {rd }}$ ed. Philadelphia: Lippincott Williams \& Wilkins; 2007.

21. Gupta G, Chhabra S, Singh K. Innovative method of teaching Histology. International Journal of Recent Advances in Pharmaceutical Research 2012; 2(1):33-36.

22. Amin NF. Trends in the presentation of cell biology and histology in contemporary histology books as revealed in their 'preface's. BSMMU Journal 2012; 5(1):46-54.

23. Wood RI, Schechter JE. Histology: an interactive virtual microscope. 2002. (Available from: http://icb.oxfordjournals.org/content/43/ 2/360.full, [accessed on June 25, 2014])

24. Moran DT, Rowley JC. Histology text atlas book. (Available from: www.visualhistology. com/products/atlas/VHA_Appendix.html, [accessed on January 19, 2014])

25. Reygel P, Lambrichts I, Vandenabeele F. Student-centred biology education: experiences with developing and teaching 'structure and function of cells and tissues'. (Available from: Intl.concord.org/cbe/pdf/ reygel.pdf, [accessed on January 19, 2014])

26. Tanner K, Allen D. Approaches to cell biology teaching: a primer on standards. Cell Biology Education 2002; 1:95-100.

27. Faculty of Medicine Ain Shams University Undergraduate Program Course Specification, 2012. (Available at:Me.asu.edu.ge/upfads/ med/student\%20affairs/course_spects_ $1^{\text {st }}$ yr_a.pdf [accessed on January 25, 2014]) 